\title{
Reducing Students' Cognitive Load by Developing Rotation Learning in Blended Setting
}

Luh Putu Putrini Mahadewi ${ }^{1}$, Anak Agung Gede Agung ${ }^{2}$, Alexander Hamonangan Simamora ${ }^{3}$

\{lpp-mahadewi@undiksha.ac.id ${ }^{1}$, agung2056@undiksha.ac.id ${ }^{2}$, alexander.simamora@ undiksha.ac.id $\left.{ }^{3}\right\}$

${ }^{1,2,3}$ Universitas Pendidikan Ganesha, Indonesia

\begin{abstract}
The purpose of the study is to test the effectivity of the innovative delivery learning strategy on students taking courses in blended setting. The academic teaching technique was designed with reference to the blended learning rotation models in order to reduce students' cognitive load. This study was a development research and the model used to develop it was the Hannafin and Peck Model. Questionnaires, tests and surveys were used to collect data. The extracted data were then analysed using descriptive and ttest techniques. The results showed that the innovative delivery learning strategy was effective to reduce students' cognitive load. However, further in-depth study is required to study the effect of the cognitive load in both face to face, and online learning settings.
\end{abstract}

Keywords: blended learning, rotation, development, cognitive load

\section{Introduction}

The rapid development and growth of information communication and technology (ICT) in this industrial revolution, has tremendous impact on human life in every sector including the educational industry. Learning without the limitations of time and place is one of the impacts. As a result of this, educational teaching strategy has changed from the traditional face to face classroom technique to online learning or both (blended). Developing the blended learning technique, requires the integration of the traditional face to face approach and online learning technique which utilizes ICT tools, while focusing on the pedagogy approach on how best to instill knowledge on students[1]. One of the approaches is based on the cognitive load theory (CLT). Students can easily master the knowledge and skills by relating and managing all the relevant information appropriately else they will gain cognitive load. According to Clark, Nguyen, and Sweller, [2] there are three types of CLT: intrinsic, extraneous and germane cognitive load.The loads that can be control by instructional designers are extraneous and germane cognitive loads. Thus, the development of a blended learning model using a certain technique that can reduce students' cognitive load is urgently needed.

One of such technique is the rotation models. It consist of four types: station, lab flipped classroom, and individual rotation models [3]. This academic teaching strategy is developed to 
create learning strategies that will aide reduce cognitive load on students. The goal is to test the effectivity of the innovative teaching strategy on students using the blended setting.

\section{Methodology}

The study is a development research referencing Hannafin and Peck development research model [4]. Questionnaires, tests and surveys were used to collect data. Questionnaires were used to collect data. Tests were conducted to ascertain the effectiveness of the rotation models, while surveys were used to analyze students' satisfaction level. [5]The collected data were then analyzed using descriptive technique. Finally, the t-test was used to test the effectiveness of the developed blended learning rotation models.

\section{Results and Discussion}

Based on the method, the following results were found.

\subsection{The Developed Blended Learning Rotation Model}

The developed blended learning rotations model were built with reference to Hannafin and Peck development model. The procedures were: conducting needs analysis, designing, developing and implementing the blended learning model. The design of the content and the type of rotation models of the blended learning can be seen on Table 1.

Table 1. The design of the content for blended learning .

\begin{tabular}{cll}
\hline Number & The learning content & $\begin{array}{l}\text { Types of rotation } \\
\text { models }\end{array}$ \\
\hline 1 & The types of learning activities & Station \\
2 & Pre-Seminar & Lab \\
3 & Educational Technology Problematic & Flipped Classroom
\end{tabular}

The screenshot of the blended learning course for online setting can be seen in Fig. 1. 


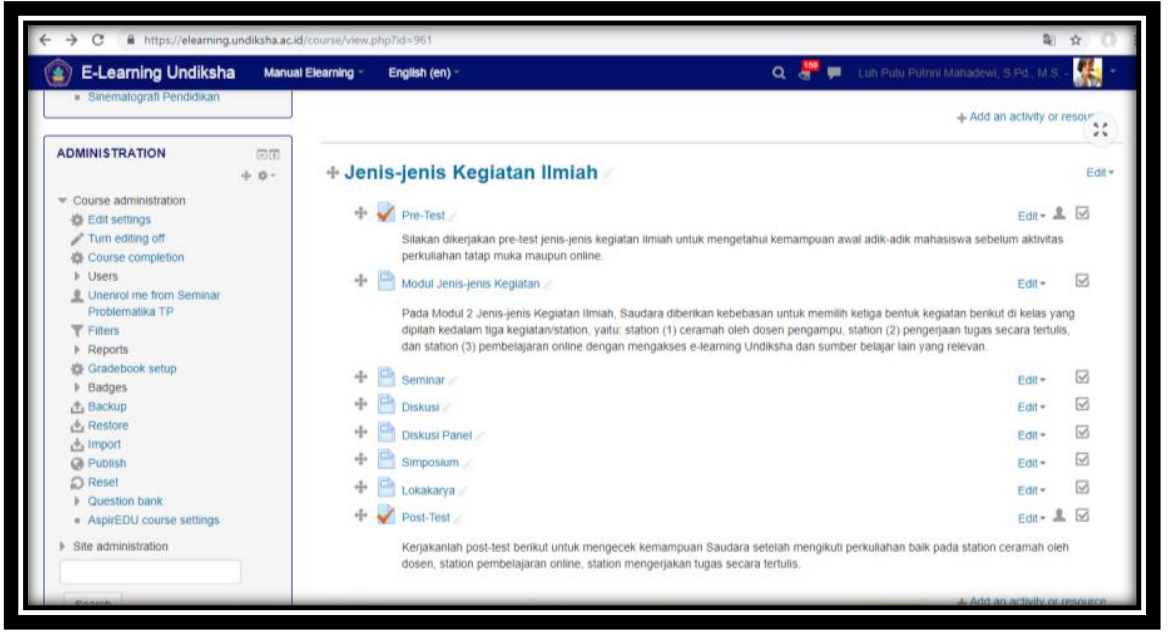

Fig. 1. Screenshot of blended learning type rotation models.

\subsection{The Validity of the Blended Learning Type Rotation Models}

The developed blended learning rotation models (station, lab r, flipped, and classroom) on Seminar of Educational Problematic Course viewed from instructional designer and learning media experts were valid [5]. Instructional design validator was used in its field and applied to the learning media. The instructional design expert assessed that the developed blended learning rotation models meet with students' needs, as it was developed with face to face and online sessions thereby, making it flexible for students. Similarly, the learning media expert assessed that the learning media used matched with students' and contents' characteristics, with a smooth and easy navigation technique. Thus, the designed rotation models can be implemented in both face to face and online sessions.

\subsection{The Effectiveness of the Blended Learning Type Rotation Models}

The valid blended learning with the three rotation models was implemented to ascertain its effectivity on students. [6] The best way to assess impact is by using surrogate measures and one of them is students' grades. The t-test showed the results as illustrated in Table 2.

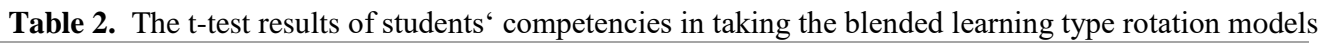

\begin{tabular}{|lllll|}
\hline & & & \\
\hline 1 & Station rotation model & 4,03 & 2,12 & Significant improvement \\
2 & Lab rotation model & 4,88 & 2,12 & Significant improvement \\
3 & Flipped classroom & 1,95 & 2,12 & Improve but not significant \\
\hline
\end{tabular}


Therefore, statistically, the developed learning models were effective in enhancing students' competencies on Seminar of Educational Problematic Course.

\subsection{Students' ${ }^{\natural}$ Satisfaction in Taking the Blended Learning Type Rotation Models}

From the implementation of the blended learning type rotation models on Educational Problematic Courses, the students stated that they were satisfied in developed learning model. Their reasons were: it's easy to access just by using computational devices (laptop, smartphone), and it is dynamic. This result is in line with the research conducted by Ugur, Akkoyunlu, and Kurbanoglu. [7] They found out that students' views on blended learning were generally very positive because the easy use of web and, online environment, face to face sessions, assessment academic contents.

\section{Conclusion}

Based-on the results and discussion, the following conclusion were made. The developed blended learning type rotations models was valid and effective in enhancing students' competencies. The students were satisfied in using the developed model to learn difficult courses; however,some improvements must be made to increase students' competencies.

\section{References}

[1] George-Walker, L.D., \& Keeffe, M.: Self-determined blended learning: a case study of blended learning design. Higher Education Research \& Development. Vol 29 Number 1, pp. 1-13 (2010).

[2]Clarck, R.C., Nguyen, F., Sweller, J.: Efficiency in Learning: Evidence-Based Guidelines to Manage Cognitive Load. San Francisco (2006).

[3] Staker, H., \& Horn, M.B.,“Classifying K-12 Blended Learning, “ 20-Jan-2018. [Online]. Available:christenseninstitute.org

[4] Qureshi, E., "Instructional Design Models, “ 20-Jan-2018.[Online]. Available: web2.uwindsor.ca/courses/edfac/morton/instructional_design.htm

[5] L.P.P. Mahadewi, "The Development of Blended Learning Type Rotation Models," 06Jan-2019. [Online]. Available: osf.io/avwex.

[6] Dziuban, C., Graham, C.R., Moskal, P.D., Norberg, A., Sicilia, N.,"Blended learning: the new normal and emerging technology,"15-02-2018. [Online]. Available: educationaltechnologyjournal.springeropen.com/articles/10.1186/s41239-017-0087-5.

[7] Ugur, B., Akkoyunlu, B., Kurbanoglu, S.,"Student's opinions on blended learning and its implemention in terms of their learning styles", 06-01-2019. [Online]. Available:researchgate.net/publication/227207529. 